\begin{tabular}{|c|c|c|}
\hline 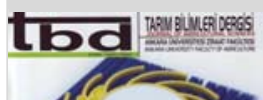 & $\begin{array}{c}\text { Tarım Bilimleri Dergisi } \\
\text { Tar. Bil. Der. }\end{array}$ & Journal of Agricultural Sciences \\
\hline & $\begin{array}{c}\text { Dergi web sayfası: } \\
\text { www.agri.ankara.edu.tr/dergi }\end{array}$ & $\begin{array}{c}\text { Journal homepage: } \\
\text { www.agri.ankara.edu.tr/journal }\end{array}$ \\
\hline
\end{tabular}

\title{
Effects of Different No-Till Seeders and Tractor Forward Speeds on the Soil Physical Properties and Seed Emergence of Summer Vetch and Winter Wheat
}

\author{
Sefa ALTIKAT ${ }^{\mathrm{a}}$, Ahmet ÇELIK ${ }^{\mathrm{b}}$ \\ ${ }^{a}$ Iğdır University, Faculty of Agriculture, Department of Biosystem Engineering, Iğdır, TURKEY \\ ${ }^{b}$ Atatürk University, Faculty of Agriculture, Department of Agricultural Machinery, Erzurum, TURKEY
}

\section{ARTICLE INFO}

Research Article - Agricultural Technologies DOI: 10.1501/Tarimbil 0000001189

Corresponding author: Sefa ALTIKAT, e-mail: sefa.altikat@igdir.edu.tr, Tel: +90(476) 2261023 /2016

Received: 06 January 2012, Received in revised form: 15 March 2012, Accepted: 10 April 2012

\begin{abstract}
The aim of this study is to determine the effects of different no-till seeders and tractor forward speeds on some of soil physical properties and seed emergence of summer vetch and winter wheat. In the research, three different types no-till seeders with hoe (NS-1), single disc (NS-2) and winged hoe (NS-3) type openers were used with four different tractor forward speeds $\left(0.75 \mathrm{~m} \mathrm{~s}^{-1}, 1.25 \mathrm{~m} \mathrm{~s}^{-1}, 1.75 \mathrm{~m} \mathrm{~s}^{-1}\right.$ and $\left.2.25 \mathrm{~m} \mathrm{~s}^{-1}\right)$. According to obtained results, the no-till seeders with hoe type furrow opener (NS-1) provided better soil physical properties than the other two no-till seeders. However, tractor forward speeds had no effect on physical properties of soil for both summer vetch and winter wheat. No-till seeders had a significant effect on the mean emergence time (MET) and percentage of emergence (PE) while tractor forward speeds had no effect on these values in both summer vetch and winter wheat. The highest PE was observed at the plots sown with NS-1 seeder in both summer vetch and winter wheat.

Keywords: No-tillage; Furrow opener; Aggregate size; Penetration resistance; Bulk density
\end{abstract}

\section{Farkı Doğrudan Ekim Makinaları ve İlerleme Hızlarının Yazlık Fiğ ve Kışılı Buğdayda Toprağın Bazı Fiziksel Özellikleri ile Bitki Çıkışına Olan Etkileri}

\section{ESER BİLGİSI}

Araştırma Makalesi - Tarım Teknolojileri

Sorumlu Yazar: Sefa ALTIKAT, e-posta: sefa.altikat@igdir.edu.tr, Tel: +90(476) 2261023 /2016

Geliş tarihi: 06 Ocak 2012, Düzeltmelerin gelişi: 15 Mart 2012, Kabul: 10 Nisan 2012

\section{ÖZET}

Araştırmada; yazlık fiğ ve kışlık buğdayda, farklı gömücü ayaklara sahip 3 adet doğrudan ekim makinası ile 4 farklı traktör ilerleme hızının toprağın bazı fiziksel özellikleri ile bitki çıkışlarına olan etkilerinin belirlenmesi amaçlanmıştır. Denemeler sırasında, çapa (NS-1) tek diskli (NS-2) ve kanatlı çapa (NS-3) tip gömücü ayaklara 
sahip üç farklı doğrudan ekim makinası dört farklı traktör ilerleme hızında $\left(0.75 \mathrm{~m} \mathrm{~s}^{-1}, 1.25 \mathrm{~m} \mathrm{~s}^{-1}, 1.75 \mathrm{~m} \mathrm{~s}^{-1}\right.$ ve 2.25 $\mathrm{m} \mathrm{s}^{-1}$ ) kullanılmıştır. Elde edilen sonuçlara göre en iyi toprak fiziksel özellikleri çapa tip gömücü ayaklara sahip doğrudan ekim makinasının kullanıldığı parsellerde gözlenmiştir. Traktör ilerleme hızlarının toprağın fiziksel özelliklerine olan etkileri her iki bitkide de istatistiksel olarak önemsiz bulunmuştur. Ortalama çıkış süresi ve çimlenme oranı yüzdelerine her iki bitkide de doğrudan ekim makinaları önemli düzeyde etkili olurken, benzer etki traktör ilerleme hızlarında gözlenmemiştir. Yazlık fiğ ve kışlık buğdayda en yüksek çıkış oranı, çapa tip gömücü ayaklara sahip doğrudan ekim makinasıyla ekim yapılan parsellerde elde edilmiştir.

Anahtar sözcükler: Doğrudan ekim; Gömücü ayak; Toprak parçacık büyüklüğü; Penetrasyon direnci;Hacim ağırlı̆̆ı

(C) Ankara Üniversitesi Ziraat Fakültesi

\section{Introduction}

No-till farming is economically viable, erosion limiting crop production system in which the crop is planted directly into the previous crop's stubble with minimum soil disturbance. In comparison with the conventional tillage method, the notillage sowing not only leads to further nitrogen accumulation in the soil but also improves soil aggregation and moisture holding capacity. In addition, the no-tillage increases $\mathrm{N}$ and $\mathrm{C}$ concentration, microbial carbon mass, and bacterial and fungal population reduces emission of $\mathrm{CO}_{2}$ and $\mathrm{N}_{2} \mathrm{O}$ gases, fuel consumption and soil erosion and increases crop yield in the long production period (Huang et al 2008; Akbolat et al 2009).

No-till sowing requires a special seeder that will effectively penetrate untilled soil and place the seed at the optimum depth for rapid plant emergence. No-till seeders and drills must be able to cut and handle stubble, penetrate the soil to the proper sowing depth, and establish good seed-tosoil contact.

A furrow opener is an important component of a seed drill or a planter. In general, a furrow opener cuts a furrow and allows the seeds to be deposited before being partially covered with soil. The types of furrow openers used vary with soil type and operating conditions. Common types of furrow openers used for minimum and no tillage systems are hoe, chisel and disc type openers (Altikat \& Celik 2011b).

Disc-type openers are prone to pushing the crop residue into the seed zone or having the openers ride over the crop residue and deposit seed on the soil surface. Either of these scenarios can reduce germination and stand establishment
(Hyde et al 1987; Lindwall \& Anderson 1977).

Chaudhuri (2001) reported that, disc-type furrow openers had minimum depth variation and the soil disturbance was also less than hoe-type furrow openers. However, hoe-type openers found to be suitable for both conventional and no- tillage systems. Under no-tillage conditions, they generally performed better than disc-type openers.

Tessier et al (1991) also evaluated the influence of no-till opener designs on furrow compaction, soil water potential, temperature regimes, plant emergence rate and plant population of spring and winter wheat. According to obtained results, the hoe and tri-disc openers had a greater variation under the drier soil conditions of spring than the moist soil conditions. Disc-type openers in general caused less soil disturbance as compared to the hoe-type openers. The hoe and tri-disc openers, however, gave significantly higher seed emergence than other openers in the autumn. However the spring, the ofset type disc openers gave better seed emergence than the hoe side-band openers.

Damora \& Pandey (1995) reported that hoetype openers buried the seed at the required depth, whereas shoe and shovel-type openers buried the seed shallower than the target depth. In the research the shoe-type opener caused a minimum variation in seeding depth. The hoe-type openers gave significantly greater lateral and vertical separation of seed and fertilizer as compared to the shoe and shovel-type openers. Soil disturbance was highest for the hoe-type openers due to asymmetric shape of the opener. As a result, the overall performance index of the hoe-type openers was better as compared to the other shoe and shovel-type openers. 
Karayel (2009) evaluated the performance of a modified precision vacuum seeder for no-till sowing of maize (Zea mays L.) and soybean (Glycine $\max$ L.) following wheat (Triticumaestivum). In the research a wavy-edged disc and side gauge wheels were fabricated and mounted to each unit of a common precision vacuum seeder (with a hoe opener on one row unit and a double disc-type opener on another row unit) and used to sow at three forward speeds (1.0, 1.5 and $2.0 \mathrm{~m} \mathrm{~s}^{-1}$ ). According to obtained results, sowing depth uniformity, mean emergence time and percent emergence of both maize and soybean seeds were decreased and precision of the distribution of the seeds along the length of the row was increased as a result of increasing forward speed. The distribution of the seeds along the length of the row, sowing depth uniformity and percent emergence of the seeder equipped with the double disc-type opener was better than the seeder equipped with the hoe-type opener.

The aim of this study is to determine the effects of no-till seeders with different furrow openers and tractor forward speeds on some soil physical properties and seed emergence of summer vetch and winter wheat.

\section{Material and Methods}

The experiment was conducted at the research farm of Ataturk University, Erzurum, Turkey in 2008 and 2009 growing seasons. The region shows characteristics of the continental climate, with a short hot period during summer and a long cold period during winter.

The classification of soil texture of the experimental field was loam. The experimental field was flat with a slope less than $1 \%$. The annual total precipitation was $371 \mathrm{~mm}$ and 378 $\mathrm{mm}$ in 2008 and 2009 respectively. The annual mean temperature in 2008 was $5^{\circ} \mathrm{C}$ with a monthly maximum of $21^{\circ} \mathrm{C}$ in August and a minimum of $-10^{\circ} \mathrm{C}$ in January, and in 2009 the annual mean temperature was $4^{\circ} \mathrm{C}$ with a monthly maximum of $22^{\circ} \mathrm{C}$ in August and a minimum of $9^{\circ} \mathrm{C}$ in January.

In August 2008, winter wheat was harvested from the experiment area using a combine harvester with a stubble height of $12 \mathrm{~cm}$, and the field was left for the winter without conducting any other process. In April 2009, summer vetch was sowed on the same area using the no-tillage method. In August 2009, the summer vetch was harvested using a lawnmower with a stubble height of $10 \mathrm{~cm}$. In the last week of September 2009, after harvesting the summer vetch, a winter wheat experiment was prepared under stubbly vetch field conditions. Table 1 illustrates some of the important soil physical properties of the experiment area.

Table 1-Some important soil physical properties in the experiment area $(0-10 \mathrm{~cm})$

Çizelgel-Deneme alanı topră̆ının önemli bazı

fiziksel özellikleri $(0-10 \mathrm{~cm})$

\begin{tabular}{lcc}
\hline $\begin{array}{l}\text { Soil physical } \\
\text { properties }\end{array}$ & $\begin{array}{c}\text { Summer } \\
\text { vetch }\end{array}$ & $\begin{array}{c}\text { Winter } \\
\text { wheat }\end{array}$ \\
\hline Bulk density, $\mathrm{Mg} \mathrm{m}^{-3}$ & 1.47 & 1.68 \\
\hline Porosity, & $44.53 \%$ & $36.6 \%$ \\
\hline Moisture content, \% d.b. & $18.21 \%$ & $6.14 \%$ \\
\hline Penetration resistance, $\mathrm{MPa}$ & 0.89 & 1.71 \\
\hline $\begin{array}{l}\text { Field surface stubble } \\
\text { covering rate }\end{array}$ & $90.3 \%$ & $88.71 \%$ \\
\hline Stubble height, cm & 12 & 12 \\
\hline Soil texture class & \multicolumn{2}{c}{ Loam } \\
\hline Sand & \multicolumn{2}{c}{$48.44 \%$} \\
\hline Clay & \multicolumn{2}{c}{$12.06 \%$} \\
\hline Silt & \multicolumn{2}{c}{$39.5 \%$} \\
\hline
\end{tabular}

The layout of the experiment was a randomized complete block design, with a factorial arrangement of treatments consisting of three no-till seeders and four tractor forward speeds at the sowing with three replications. The experimental plots were $30 \mathrm{~m}$ long and $3 \mathrm{~m}$ wide.

Three no-till seeder types (Figure 1) were different from each other for their furrow opener types; hoe (NS-1), single disc (NS-2) and winged hoe (NS-3). The hoe type furrow opener seeder (NS-1) was an Amazone/NT 250 No- till seeder (Amazonen-Werke H. Dreyer GmbH \& Co. KG, Hasbergen, Germany), the single disc type furrow opener seeder (NS-2) was an Özdöken No- till seeder (Özdöken Agricultural Machinery Co. Konya/ Turkey) and the winged hoe type furrow 


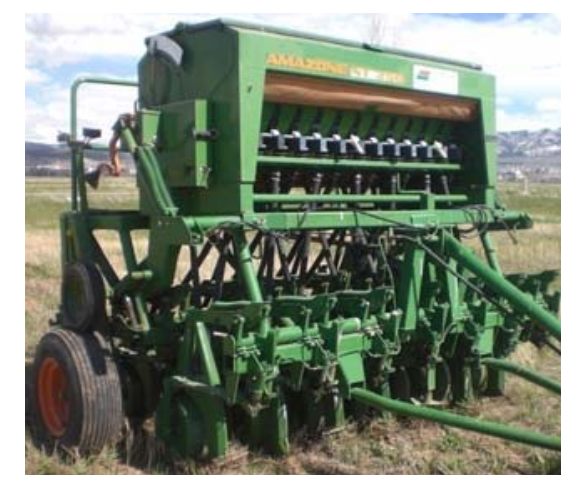

Amazone/NT 250 No- till seeder (NS-1)

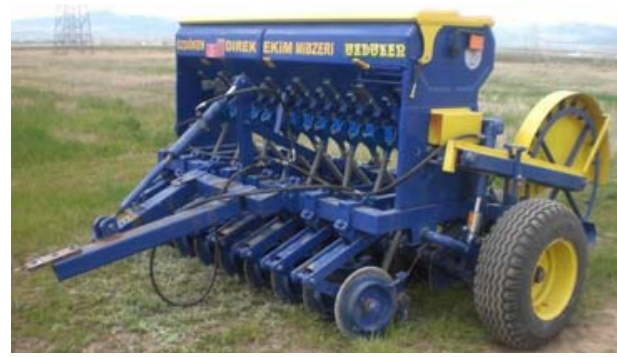

Özdöken No- till seeder (NS-2)

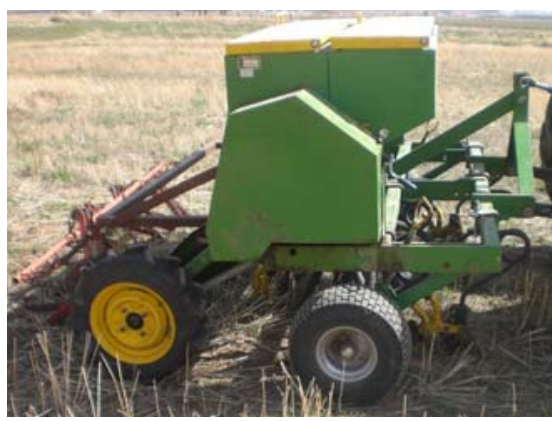

Aitchison / Seed Matic No-till seeder (NS-3)

Figure 1-No-till seeders and furrow openers

Şekil 1-Doğrudan ekim makinalart ve gömücü ayaklar

opener seeder (NS-3) was an Aitchison / Seed Matic No-till seeder (Reese Engineering LTD. Geelong, Victoria, Australia). Table 2 illustrates some of the important technical properties of notill seeders. In the research, tractor forward speeds were; V1: $0.75 \mathrm{~m} \mathrm{~s}^{-1}, \mathrm{~V} 2: 1.25 \mathrm{~m} \mathrm{~s}^{-1}, \mathrm{~V} 3: 1.75 \mathrm{~m}$

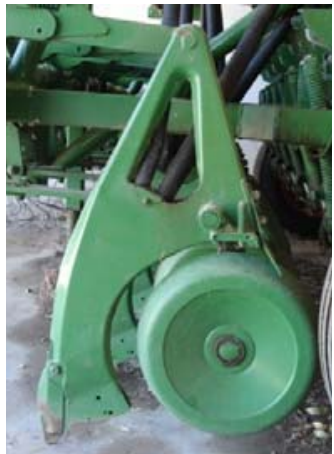

Hoe type furrow opener for the Amazone/NT 250 Notill seeder. Direction of forward travel is right to left

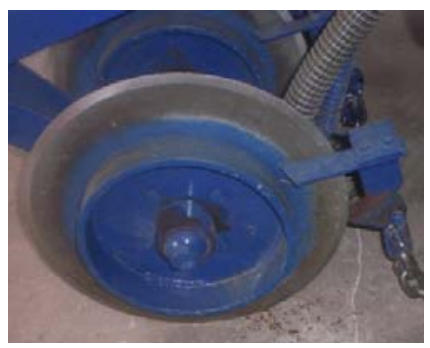

Single disc type furrow opener for the Özdöken No-till seeder. Direction of forward travel is right to left.

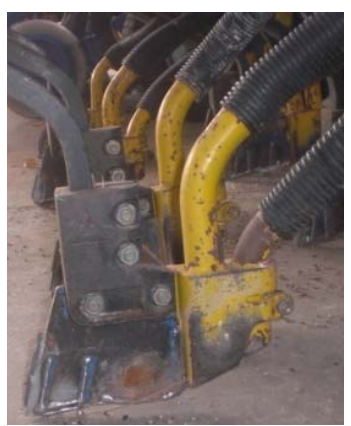

Winged hoe type furrow opener for the Aitchison / Seed Matic No-till seeder. Direction of forward travel is right to left.

\section{$\mathrm{s}^{-1}, \mathrm{~V} 4: 2.25 \mathrm{~m} \mathrm{~s}^{-1}$.}

Tillage implements were pulled by a Massey Ferguson 365 S tractor. A True Ground Speed radar and a DJCMS 100 monitor made by Tracktometer was used to achieve the tractor forward speed. 
Table 2-Some technical properties of no-till seeders

Çizelge 2-Doğrudan ekim makinalarının bazı teknik özellikleri

\begin{tabular}{lccc}
\hline Technical properties & NS-1 & NS-2 & NS-3 \\
\hline Types of furrow opener & Hoe & Single disc & Winged hoe \\
\hline Number of openers & 16 & 15 & 8 \\
\hline Total weight, kg & 1400 & 1000 & 534 \\
\hline Manufacturer and model & Amazone / 250 NT & Özdöken & Aitchison / Seed Matic \\
\hline
\end{tabular}

For the experiment, Ebena type summer vetch seed and Bezostaja type winter wheat seed were sowed with $140 \mathrm{~kg} \mathrm{ha}^{-1}$ and $165 \mathrm{~kg} \mathrm{ha}^{-1}$ seed rate and at $50 \mathrm{~mm}$ sowing depth, respectively. The winter wheat seeds were disinfected with powder fungicide DS-2 before sowing. DAP (18\% AN, $46 \% 46 \mathrm{P}_{2} \mathrm{O}_{5}$ ) fertilizer was used at a norm of 150 $\mathrm{kg} \mathrm{ha}^{-1}$ in sowing time of both summer vetch and winter wheat.

Measurements were taken both before and after the experiment in order to determine the soil bulk density of the experiment area. 10-cm deep soil samples at $5-\mathrm{cm}$ intervals were taken from every plot, and then placed in a $105^{\circ} \mathrm{C}$ drying oven for 24 hours to dry after being weighed; this process was repeated three times. The samples removed from the drying oven were re-weighed to determine their dry weight. The bulk density and porosity was calculated by taking into consideration the dry weight of soil samples and the specific density of the experiment area soil (Celik \& Altikat 2010).

After sowing, an Eijkelkamp soil cone penetrometer (Eijkelkamp Agrisearch Equipment, Giesbeek, The Netherlands), with an analogue indicator was used for the measurement of penetration resistance. For each plot, measurements were repeated three times (Altikat \& Celik 2011a).

To determine aggregate size distribution of the soil, soil samples were randomly taken from tilled plots immediately after sowing, with three replications, using a spade from a depth of 0-10. Soil samples were air dried at room temperature for 2 months. The air dried samples were sieved using a set of sieves (mesh openings of 63, 32, 16, $8,4,2$ and $1 \mathrm{~mm}$ ) with a shaking time of $30 \mathrm{~s}$ and $50 \mathrm{~Hz}$ (Eghball et al 1993). The evaluation of the data obtained from sieving took into account the seedbed soil aggregate size demands. Thus, sieved soil was classified into three major groups.

The first group was $<1 \mathrm{~mm}$, the second group 1-8 $\mathrm{mm}$, and the third group $>8 \mathrm{~mm}$ (Altikat \& Celik, 2011a). Data from published sources states that the soil aggregate size for the best seedbed is between 1 and $8 \mathrm{~mm}$ diameters (Adam \& Erbach 1992, Logsdon et al 1987). In addition to these aggregate size groups, the mean weight diameter (MWD) was used to evaluate the overall soil aggregates distribution (Berntsen \& Bere 2002). The aggregate size distribution was determined based on the weight of soil aggregates in each class, with respect to the total soil sample weight.

Seedling counts were carried out at two days intervals, starting from the beginning to the end of the emergence at $1 \mathrm{~m}$ length rows in each plot with three replications. The mean emergence time (MET) and percentage of emergence (PE) were determined using the following equations (Altikat $\&$ Celik 2011a):

$$
\begin{aligned}
& \text { MET }=\frac{\mathrm{N}_{1} \mathrm{~T}_{1}+\mathrm{N}_{2} \mathrm{~T}_{2}+\ldots . .+\mathrm{NnTn}}{\mathrm{N}_{1}+\mathrm{N}_{2}+\ldots . . . \mathrm{Nn}} \\
& P E=\frac{S_{t e}}{n} x 100
\end{aligned}
$$

where; MET is mean emergence time, day; PE is percentage of emergence, $\% ; \mathrm{N}_{1} \ldots n$ is number of emerged seedlings since the time of previous count; $T_{1} \ldots_{n}$ is number of days after sowing; $S_{\text {te }}$ is total number of emerged seedlings per meter; and $\mathrm{n}$ is number of seeds sown per meter.

The ANOVA procedure, appropriate for randomized complete block design, was the procedure used to analyze the variance of the 
obtained data. Means were compared using Duncan's multiple range tests.

\section{Results and Discussion}

\subsection{Soil bulk density and penetration resistance}

The effects of seeders on the soil bulk density were statistically significant; but the forward speed was insignificant in both summer vetch and winter wheat experiments. Bulk density increased together with the increase in soil depth (Figure 2). For $0-5 \mathrm{~cm}$ and $5-10 \mathrm{~cm}$ soil depths the highest soil bulk density was obtained from plots sown with NS-1 seeder in both summer vetch and winter wheat experiments. The average soil bulk density values were $1.163 \mathrm{Mg} \mathrm{m}^{-3}$ and $1.273 \mathrm{Mg}$ $\mathrm{m}^{-3}$ for summer vetch, and $1.408 \mathrm{Mg} \mathrm{m}^{-3}$ and $1.494 \mathrm{Mg} \mathrm{m}^{-3}$ for winter wheat at $0-5 \mathrm{~cm}$ and $5-10$ cm depth respectively.

The increase in penetration resistance was similar to the soil bulk density. Penetration resistance for $0-5 \mathrm{~cm}$ depth was determined as
1.26 MPa, 1.21 MPa and 1.18 MPa for NS-1, NS2 , and NS-3, respectively in summer vetch. For 5$10 \mathrm{~cm}$ soil depth, the penetration resistance was determined as $1.28 \mathrm{MPa}, 1.24 \mathrm{MPa}$ and $1.15 \mathrm{MPa}$ for NS-1, 1 NS-2, and NS-3 respectively (Figure $3)$. As it was expected, penetration resistance increased with increase in soil depth. Penetration resistance obtained from the winter wheat experiment was found to be higher than the ones obtained from summer wetch experiment at both, $0-5$ and $5-10 \mathrm{~cm}$ depths. At $0-5 \mathrm{~cm}$ soil depth the penetration resistance was determined as 1.71 $\mathrm{MPa}, 1.70 \mathrm{MPa}$ and 1.40 MPa for NS-1, NS-2 and NS-3 no-till seeders, respectively. The highest penetration resistance was observed with NS-2 as $1.79 \mathrm{MPa}$ at $5-10 \mathrm{~cm}$ soil depth, and this followed by NS-1 (1.78 MPa) and NS-3 (1.73 MPa) no-till seeders (Figure 3 ). However, the effects of tractor forward speed on soil bulk density were found to be statistically insignificant.
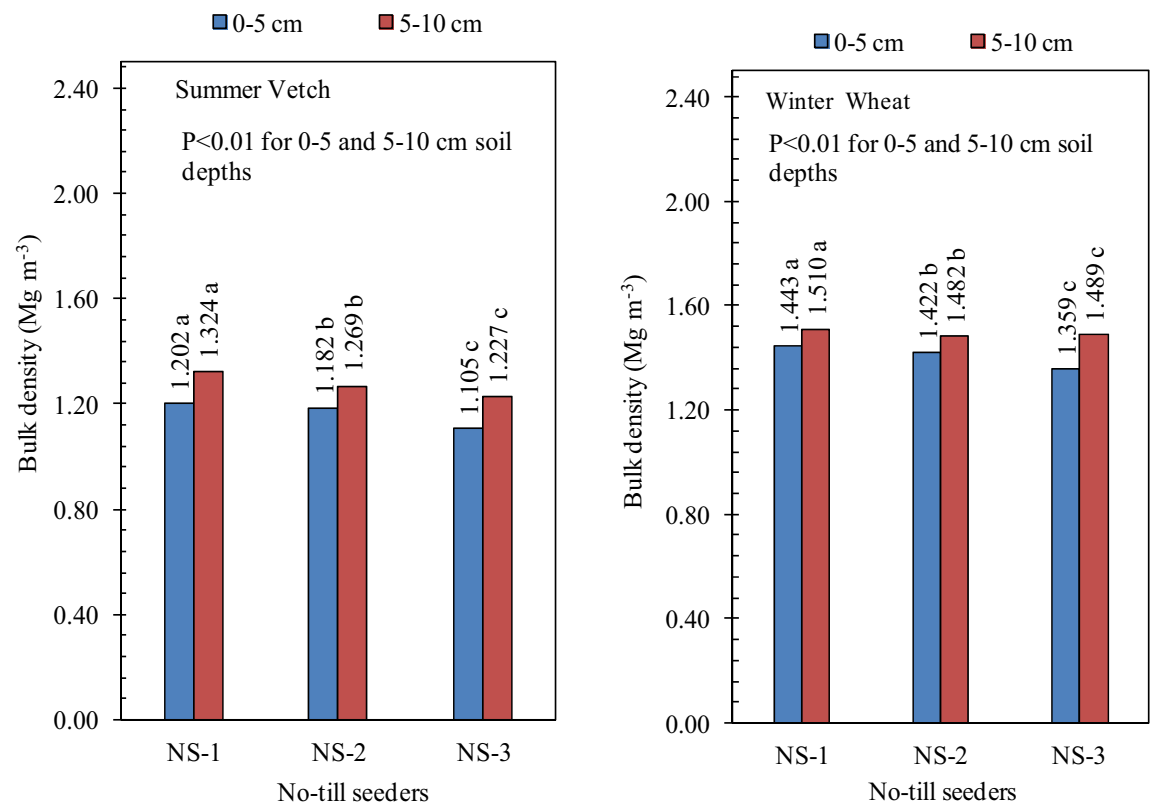

Figure 2-Effects of no-till seeders on the soil bulk density

Şekil 2-Doğrudan ekim makinalarının toprak hacim ağırlığına etkileri 

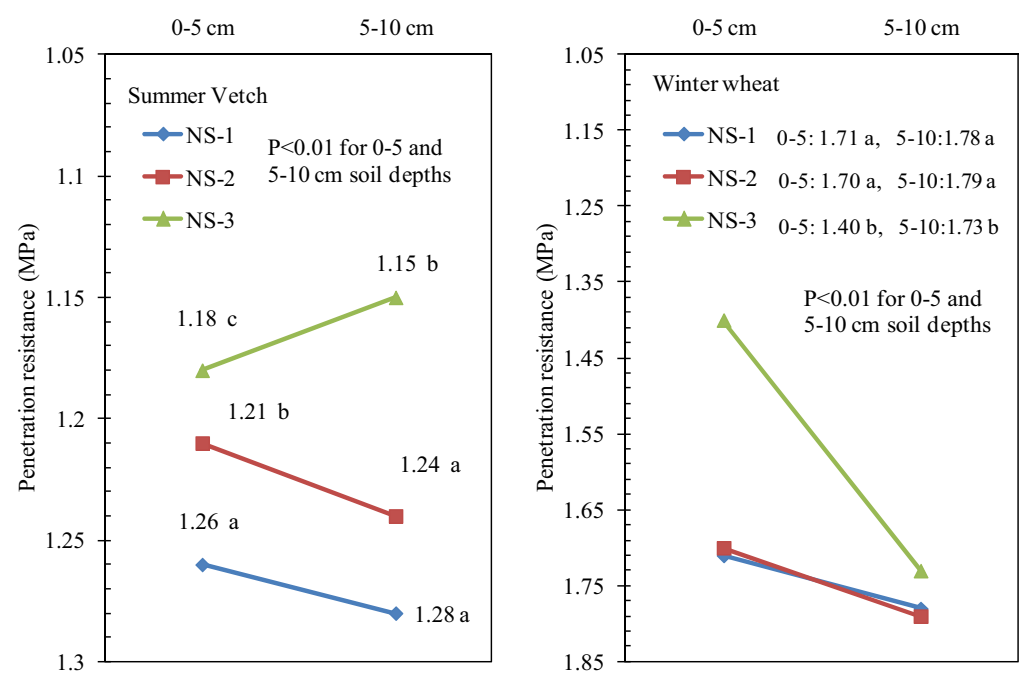

Figure 3-Effects of no-till seeders on the penetration resistance

Şekil 3-Doğrudan ekim makinalarının penetrasyon direncine etkileri

\subsection{Soil aggregate size distribution}

Aggregate size distribution has a large influence on crop emergence and therefore is a key determinant in seedbed quality. The no-till seeders significantly affected the soil aggregate size distribution in seedbed at both summer vetch and winter wheat experiments. The maximum percentage of 1-8 $\mathrm{mm}$ aggregate size was observed with the NS-1 and minimum values were obtained with NS-2 in both summer vetch and winter wheat. In the study, the highest MWD values were obtained from NS-2 with $18.68 \mathrm{~mm}$ and NS-3 with $8.14 \mathrm{~mm}$ for summer vetch and winter wheat, respectively (Table 3 ). The effects of tractor forward speed on soil aggregate size distribution were statistically significant at winter wheat experiment. The highest MWD obtained with $2.25 \mathrm{~m} \mathrm{~s}^{-1}$ tractor forward speed as $8.57 \mathrm{~mm}$ (Table 3).

\subsection{Seed emergence}

According to the results obtained from both summer vetch and winter wheat experiments, notill seeders had a significant effect on the mean emergence time (MET) and percentage of emergence (PE) while tractor forward speeds had no important effects.
In the summer vetch study, the mean emergence time was determined as 10.56 days, 10.87 days and 10.98 days for NS-1, NS-2 and NS-3 seeders, respectively while for the winter wheat study, these values were determined as 10.62 days. 10.84 days and 11.11 days for NS-1, NS-2 and NS-3 seeders, respectively (Figure 4).

The highest PE values were observed at the plots sown with NS-1 in both summer vetch and winter wheat experiments. The percentage of emergence found to be as $85.02 \%$ with NS-1, $72.87 \%$ with NS-2 and $81.07 \%$ with NS-3 seeders at the summer vetch study. These values were determined for the winter wheat study as $76.49 \%$, $76.01 \%$ and $71.72 \%$ with the NS-1. NS-2 and NS-3 seeders, respectively (Figure 4).

Some reports suggested that the no-till seeders having hoe type openers cause poorer spring wheat (Triticum aestivum L.) (Tessier et al 1991) and winter wheat (Lindwall \& Anderson 1977) emergence or yields compared to the no-till seeders having double disc openers. In contrast, Wilkins (1983) indicated that hoe type openers caused better winter wheat emergence. Similarly, $\mathrm{Du}$ et al (2004) reported that no-till seeders having hoe-type furrow openers produced 
Table 3-Means comparisons of aggregate size distribution and MWD of no-till seeder and forward speed Çizelge 3-Doğrudan ekim makinaları ve ilerleme hızlarına ait toprak parçacık dağılımı ve ağırlıklı ortalama çapların karşılaştırılması

\begin{tabular}{|c|c|c|c|c|}
\hline \multirow{2}{*}{$\begin{array}{l}\text { Treatments } \\
\text { No-till seeders (NS) }\end{array}$} & \multicolumn{4}{|c|}{ Summer vetch } \\
\hline & $<1 \mathrm{~mm}(\%)$ & $1-8 \mathrm{~mm}(\%)$ & $>8 m m(\%)$ & $M W D(\mathrm{~mm})$ \\
\hline NS-1 & $32.33 \mathrm{a}^{v}$ & $39.46 \mathrm{a}$ & $28.21 \mathrm{c}$ & $8.97 \mathrm{c}$ \\
\hline NS-2 & $14.72 \mathrm{c}$ & $22.90 \mathrm{c}$ & $62.38 \mathrm{a}$ & $18.68 \mathrm{a}$ \\
\hline NS-3 & $29.80 \mathrm{~b}$ & $36.63 \mathrm{~b}$ & $33.57 \mathrm{~b}$ & $9.80 \mathrm{~b}$ \\
\hline \multicolumn{5}{|l|}{ Analysis of variance } \\
\hline NS & $0.001 * *$ & $0.001 * *$ & $0.001 * *$ & $0.001 * *$ \\
\hline $\mathrm{FV}$ & $0.137 \mathrm{~ns}$ & $0.175 \mathrm{~ns}$ & $0.526 \mathrm{~ns}$ & $0.523 \mathrm{~ns}$ \\
\hline $\mathrm{NS} \times \mathrm{FV}$ & $0.212 \mathrm{~ns}$ & $0.706 \mathrm{~ns}$ & $0.987 \mathrm{~ns}$ & $0.983 \mathrm{~ns}$ \\
\hline Treatments & \multicolumn{4}{|c|}{ Winter wheat } \\
\hline No-till seeders (NS) & $<1 \mathrm{~mm}(\%)$ & $1-8 \mathrm{~mm}(\%)$ & $>8 m m(\%)$ & $M W D(\mathrm{~mm})$ \\
\hline NS-1 & $35.00 \mathrm{a}^{\mathrm{V}}$ & $43.37 \mathrm{a}$ & $21.63 \mathrm{~b}$ & $7.07 \mathrm{~b}$ \\
\hline NS-2 & $32.85 \mathrm{~b}$ & $42.69 \mathrm{a}$ & $24.46 \mathrm{a}$ & $8.04 \mathrm{a}$ \\
\hline NS-3 & $32.98 \mathrm{~b}$ & $43.07 \mathrm{a}$ & $23.95 \mathrm{a}$ & $8.14 \mathrm{a}$ \\
\hline \multicolumn{5}{|l|}{ Forward speeds $(F V)$} \\
\hline $\mathrm{V} 1\left(0.75 \mathrm{~ms}^{-1}\right)$ & $31.95 \mathrm{~d}$ & $41.16 \mathrm{c}$ & $26.89 \mathrm{a}$ & $7.14 \mathrm{c}$ \\
\hline $\mathrm{V} 2\left(1.25 \mathrm{~ms}^{-1}\right)$ & $33.14 \mathrm{c}$ & $43.49 \mathrm{~b}$ & $23.37 \mathrm{~b}$ & $7.54 \mathrm{~b}$ \\
\hline V3 $\left(1.75 \mathrm{~ms}^{-1}\right)$ & $34.23 \mathrm{~b}$ & $43.12 \mathrm{~b}$ & $22.65 \mathrm{~b}$ & $7.74 \mathrm{~b}$ \\
\hline V4 $\left(2.25 \mathrm{~ms}^{-1}\right)$ & $35.12 \mathrm{a}$ & $44.39 \mathrm{a}$ & $20.49 \mathrm{c}$ & $8.57 \mathrm{a}$ \\
\hline \multicolumn{5}{|l|}{ Analysis of variance } \\
\hline NS & $0.001 * *$ & $0.179 \mathrm{~ns}$ & $0.001 * *$ & $0.001 * *$ \\
\hline $\mathrm{FV}$ & $0.001 * *$ & $0.001 * *$ & $0.001 * *$ & $0.001 * *$ \\
\hline $\mathrm{NS} \times \mathrm{FV}$ & $0.257 \mathrm{~ns}$ & $0.058 \mathrm{~ns}$ & $0.119 \mathrm{~ns}$ & $0.543 \mathrm{~ns}$ \\
\hline \multicolumn{4}{|c|}{ No-till seeder having hoe type furrow opener } & Level of significance \\
\hline \multicolumn{4}{|c|}{ No-till seeder having single disc type furrow opener } & Non significant \\
\hline \multicolumn{4}{|c|}{ No-till seeder having wing hoe type furrow opener } & $P<0.01$ \\
\hline
\end{tabular}
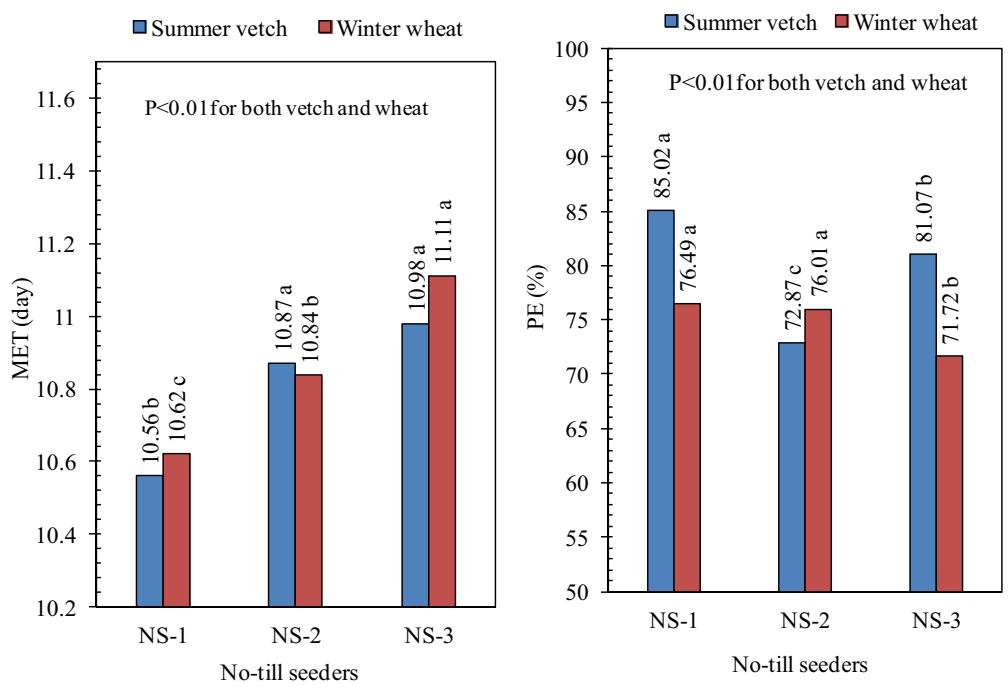

Figure 4-Effect of no-till seeders on the seed emergence

Şekil 4-Doğrudan ekim makinalarının bitki çıkışlarına etkileri

equivalent or higher wheat emergence percentages and sorghum height than a disc type furrow 
opener. However, the minimum PE values were obtained from winged hoe type furrow opener. The results obtained from this study are similar to the literature.

\section{Conclusions}

The highest soil bulk density, penetration resistance, percentage of $1-8 \mathrm{~mm}$ aggregate size and mean emergence time values were obtained with the no-till seeder having hoe type furrow opener in both summer vetch and winter wheat experiments. However, tractor forward speeds only affected soil aggregate size distribution and MWD in winter wheat. The no-till seeder with hoe type furrow opener has press wheels and these had compaction effect on the intra-row at the sowing time. Press wheel can have an effect on the machine performance and crop emergence because depth control is more homojen with press wheel. Furthermore, this seeder's weight per furrow opener was higher than other no-till seeders. Due to these reasons soil penetration resistance and bulk density found to be higher with this seeder compared to the other two no-till seeders. In addition to these, seed covering components of the seeder with hoe type furrow opener is spring type, which is known to have very good effects of closure. Consequently, the best results of soil physical properties and seed emergence rate were obtained using the no-till seeder having hoe type furrow openers.

\section{Acknowledgements}

This study was supported by the Scientific Research Unit of Ataturk University, Erzurum, Turkey.

\begin{tabular}{|ll|}
\hline \multicolumn{2}{|l|}{ Nomenclature } \\
\hline$N S-1$ & no-till seeder having hoe type furrow opener \\
$N S-2$ & no-till seeder having single disc type furrow opener \\
$N S-3$ & no-till seeder having wing hoe type furrow opener \\
$M E T$ & mean emergence time \\
$P E$ & percentage of emergence \\
$M W D$ & mean weight diameter \\
\hline
\end{tabular}

\section{References}

Adam K M \& Erbach D C (1992). Secondary tillage toll effect on soil aggregation. Transacions of the ASAE 35(6): 1771-1776

Akbolat D, Evrendilek F, Coşkan A \& Ekinci K (2009). Quantifying soil respiration in response to shortterm tillage practices: a case study in southern Turkey. Acta Agriculturae Scandinavica Section B. Soil and Plant Science 59(1): 50-56

Altikat S \& Celik A (2011a). The effects of tillage and intra-row compaction on seedbed properties and red lentil emergence under dry land conditions. Soil and Tillage Research 114: 1-8

Altikat S \& Celik A (2011b). Effects of different furrow openers, covering components and forward speeds in no till seeders on the soil surface roughness. I $\breve{g} d l r$ University Journal of the Institute of Science and

\section{Technology 1(1): 85-90}

Berntsen R \& Bere B (2002). Soil fragmentation and the efficiency of tillage implements. Soil and Tillage Research 64: 137-147

Chaudhuri D (2001). Performance evaluation of various types of furrow openers on seed drills-a review. Journal of Agricultural Engineering Research 79 (2): 125-137

Celik A \& Altikat S (2010). Effects of various strip widths and tractor forward speeds in strip tillage on soil physical properties and yield of silage corn. Journal of Agricultural Sciences 16:169-179

Damora D \& Pandey K P (1995). Evaluation of performance of furrow openers of combined seed and fertilizer drills. Soil and Tillage Research 34(1): 127-139

Du A, Bekele J E \& Morrison J R (2004). Drill furrow opener effects on wheat and sorghum establishment 
in no-till fields. Applied Engineering in Agriculture 20(2): 179-185

Eghball B, Mielke L N, Calvo G A \& Wilhelm W W (1993). Fractal description of soil fragmentation for various tillage methods and crop sequences. Soil Science Society of America Journal 57: 1337-1341

Huang G B, Zhang R Z, Lic G D, Li L L, Chan K Y, Heenan D P, Chen W, Unkovich M J, Robertson M J, Cullis B R \& Bellotti W D (2008). Productivity and sustainability of a spring wheat-field pea rotation in a semi-arid environment under conventional and conservation tillage systems. Field Crops Research 107: 43-55

Hyde G M, Wilkins D E, Saxton K E, Hammel J E, Swanson G J, Hermanson R H, Dowding E A, Simpson J B \& Peterson C L (1987). Reduced tillage seeding equipment development. In STEEP - Conservation concepts and accomplishments. Pullman, Wash.: Washington State University Publications

Karayel D (2009). Performance of a modified precision vacuum seeder for no-till sowing of maize and soybean. Soil and Tillage Research 104: 121-125

Lindwall C W \& Anderson D T (1977). Effects of different seeding machines on spring wheat production under various conditions of stubble residue and soil compaction in no-till rotations. Canadian Journal of Soil Science 57(2): 81-91

Logsdon S D, Parker J C \& Reneau R B (1987). Root growth as influenced by aggregate size. Plant and Soil 99: 267-275

Tessier S, Hyde G M, Papendick R I \& Saxton K E (1991). No-till seeder effects on seed zone properties and wheat emergence. Transactions of the ASAE 34(3):733-739

Wilkins D E (1983). Grain-drill opener effects on wheat emergence. Transactions of the ASAE 26(3): 651655 